\title{
Strategic Analysis Of The Investment Position Of South Africa On The Foreign Investment Market
}

\author{
Liliia Valerievna Matraeva \\ Russian State Social University \\ Chamber of Economic Theory and International Trade \\ Alexey Vladimirovich Belyak \\ currently works in multinational company \\ ZAO "3M Russia”
}

\begin{abstract}
This article is devoted to the investment attractiveness of the country. The authors would like to propose their own approach, using South Africa as an example. The authors demonstrate the way to analyze the investment position of the country and work out recommendations for the future development, given ready available statistical data. This method can be applied to any other country as it is based on Global Competitiveness Report covering all the countries in the world as well as UNCTAD and IMF data. Based on this data authors have prepared SWOT analysis with detailed review of strengths, weaknesses, opportunities and threats which is based on statistical data rather than on expert opinions. The analysis covers the years 2010 and 2014. The year 2010 was chosen as the first year after crisis. The year 2014 was taken because for the year 2015 there was no data regarding the level of FDI which is crucial for defining investment position. Therefore year 2014 contains the most recent data about FDI. The conducted analysis resulted in the statement that considering all the analyzed features and development factors of the country, the current position on the investment map, strengths and weaknesses, threats and opportunities, South Africa should make a choice of a strategy between the strategies for accelerated growth and limited growth in favor of the latter.
\end{abstract}

Keywords: investment position, investment attractiveness, South Africa, SWOT, Global Competitiveness Report.

JEL classification: F21, F36, F65.

\section{INTRODUCTION TO RESEARCH METHODS}

The analysis of Foreign direct investments (FDI) dynamics in South Africa covered the period starting from 1995 as it was the first year after the fall of apartheid and the year of the first general elections. Elections were won by African National Congress which is still in power. Also in 1995, South Africa was re-admitted to the Commonwealth of Nations.

SWOT scorecard of South Africa investment position was made for the year 2010 and 2014 and it was not an occasional choice. For the year 2015 there is no data regarding the level of FDI which is crucial for defining investment position. Year 2010 was chosen as the first year after the crisis.

The basis for the study is the authors' method for the investment attractiveness assessment of the country on the foreign investment market (Matraeva 2013). 
Sources of statistical information used in the analysis are as follows: data of the UN Conference on Trade and Development (UNCTAD), Global Competitiveness Report, International Monetary Fund data.

\section{ANALYSIS OF DYNAMICS IN FOREIGN INVESTMENTS FLOWS INTO SOUTH AFRICA}

Foreign Direct Investments is one of the key factors for development and integration of African countries into the world society. FDI plays important role in modern investment processes without which active innovation development of countries and intensive technological renovation of basic economy sectors in particular is almost impossible due to the lack of internal capabilities of developing countries in Africa.

South Africa is the leader of attracting FDIs in the South of Africa. FDI in the country is in focus thanks to the policy of economic development of the country chosen by the former South African President Nelson Mandela and actively supported by the modern government headed by Jacob Zuma. Following unique conditions were created in South Africa for attracting investments:

- no legal restrictions on foreign investment volume and composition;

- no requirements for minimum capital threshold for companies (with the exception of banking and insurance sector);

- no restrictions on foreign ownership of created or acquired by South African companies (with the exception of the banking and financial sector);

- no restrictions on private entrepreneurship for foreigners (Industrial policy 2001).

Main factors influencing the inflow of FDI into economy of any country are stable state of economy and favorable investment climate. One of the most influential rating agencies Moody's estimated the investment attractiveness of South Africa in 2015 as the «Baa2» average reliability (declining), and two other, equally influential Standard \& Poor's and Fitch Ratings, as the «BBB-».

In the ranking of countries in terms of business environment, which was conducted by the rating agency The Economist Intelligence Unit in 2014, South Africa occupies a respectable 54th place, ahead of Russia and India. In at least known rating for foreign direct investment of company "A. T. Kearney », which is called the index of confidence of foreign direct investors (FDI Confidence Index), South Africa took the 13th place in 2014, moving up 2 positions in comparison with 2013 year and leaving behind Japan, which fell on the 19th place.

Nevertheless according to above mentioned ratings we can conclude the South Africa has overall positive investment climate and is significantly ahead on FDI their territorial neighbors (see Figure 1) 


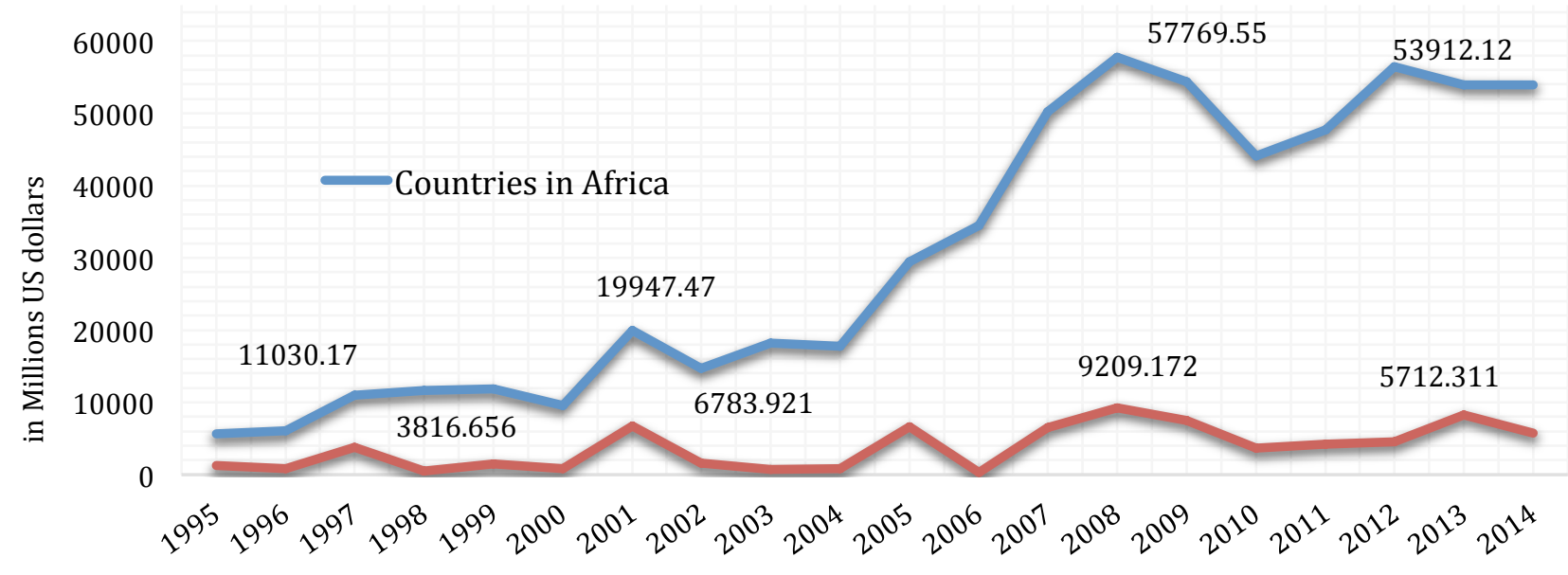

Figure 1: The dynamics of the inflow of foreign direct investment in Africa in general and South Africa in years 1995-2014 (UNCTAD 2016)

Increase of investment interest of foreign investors is partly caused by the accession of South Africa to the BRIC countries in 2010, and the fact that South Africa is the only African country in the G20.

However, in Fig. 1 is seen that the FDI trend in South Africa is similar to the general trends of foreign investment in the African continent. Throughout the reporting period, the country was in the top five in terms of attracting FDI, apart from 1998, 2004 and 2006, where was on 8th, 7 th and 18th place, respectively, while the last two years was leader on this indicator. Its average weight in the total volume of attracted FDI in Africa is approximately $11 \%$ over the past 10 years.

However the overall share of FDI attracted in South Africa in the total volume of the developing countries and in global volume is insignificant, and in 2014 was only $0.84 \%$ and $0.46 \%$, respectively (see Figure 2).

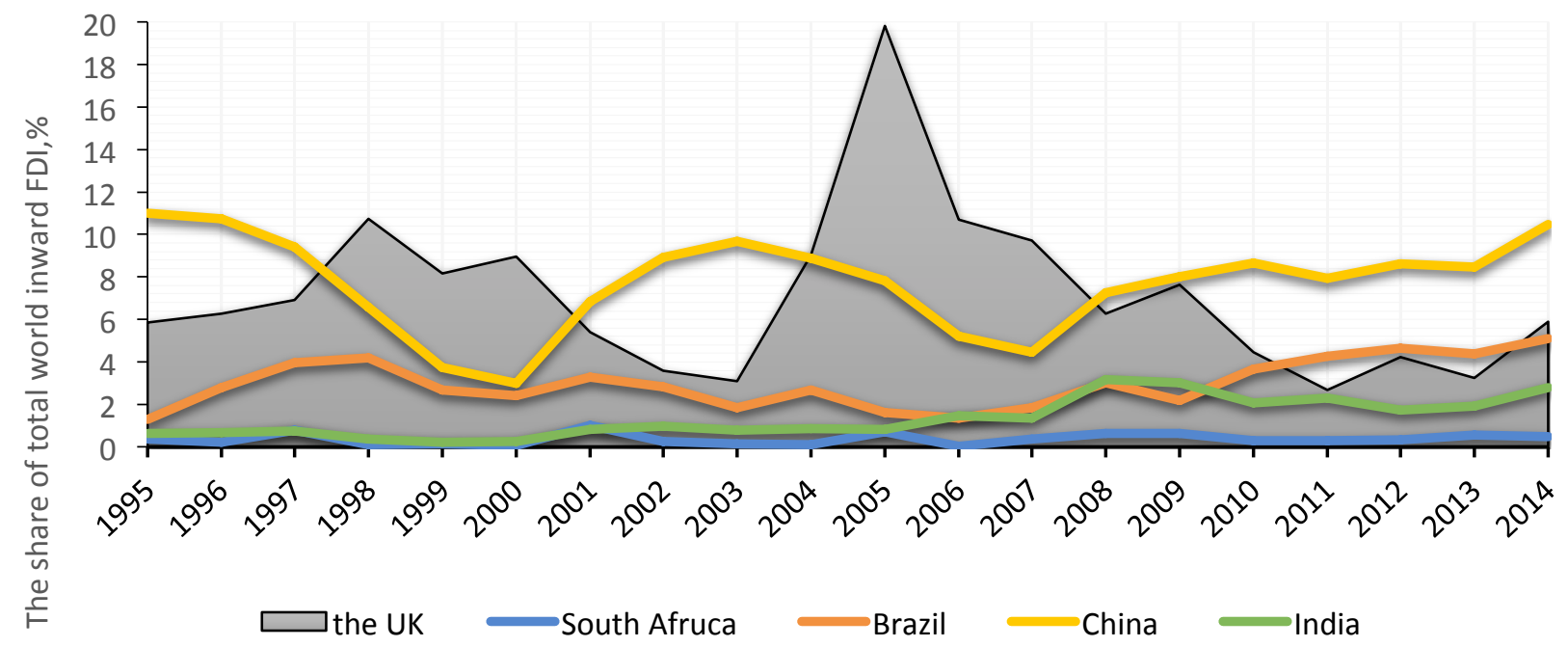

Figure 2: Share of some countries in the global level of inward FDI,\% (UNCTAD 2016)

The share of foreign direct investment in developing countries' GDP is slightly higher (an average difference of $0.76 \%$ ) than the world average. In South Africa, due to non-steady flow of 
FDI from year to year there are high fluctuations in this indicator. On average for the period under review the share of FDI in GDP of South Africa was 1.6\%, which is below the world average (see Figure 3).

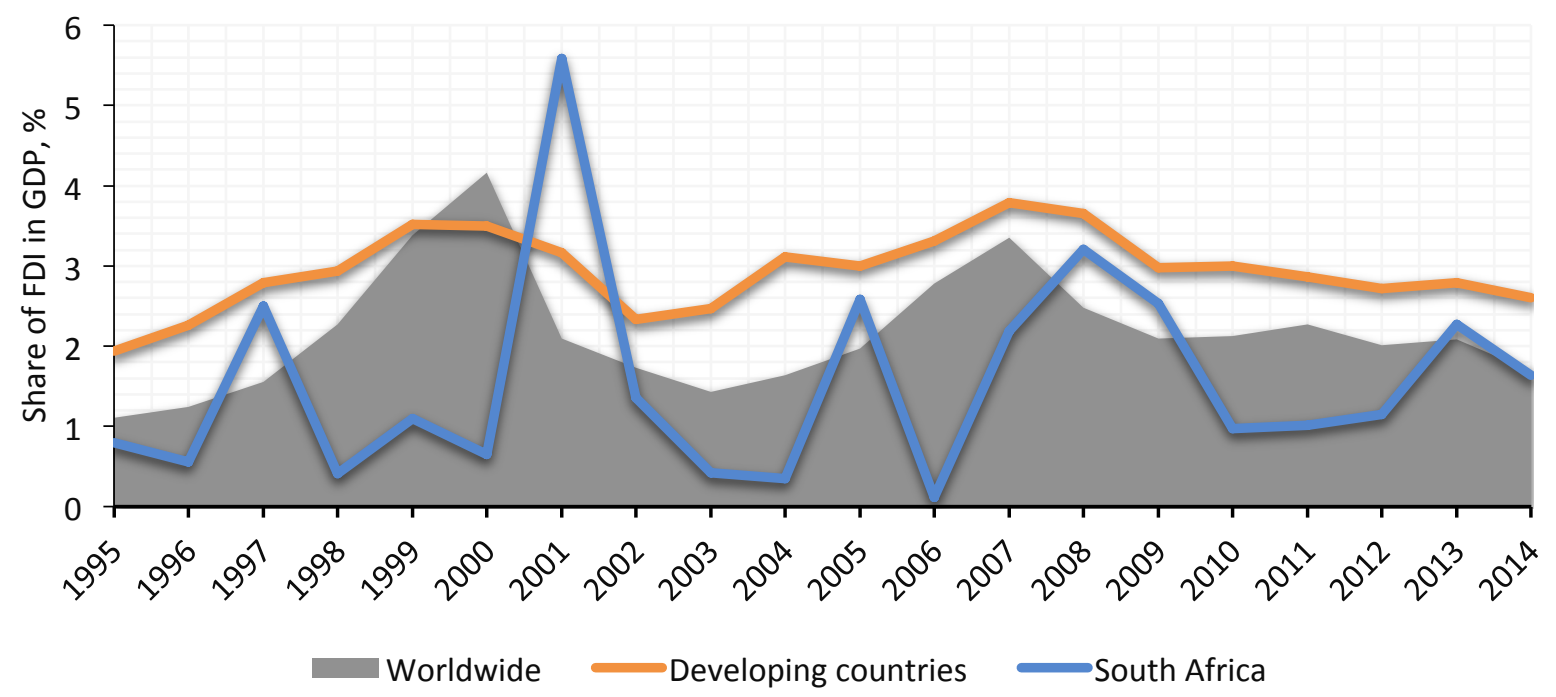

Figure 3: Share of FDI in GDP in the world, in developing countries \& in South Africa,\% (UNCTAD 2016)

Between 2007 and 2013 the main countries investing into South Africa were the US, the UK and Australia. The combined share of these countries is 44\% in FDI inflows. The US invests in various sectors of the South African economy, but most of all projects related to the automotive industry. Australia and the United Kingdom also focus on the energy sector of the country.

\section{ANALYSIS OF GLOBAL COMPETITIVENESS OF SOUTH AFRICA}

In the Global competitiveness index South African index among the other African countries is relatively solid and in 2015 overtook its neighbor in the BRICS - Brazil, slightly losing to Russia (see Figure 4.).

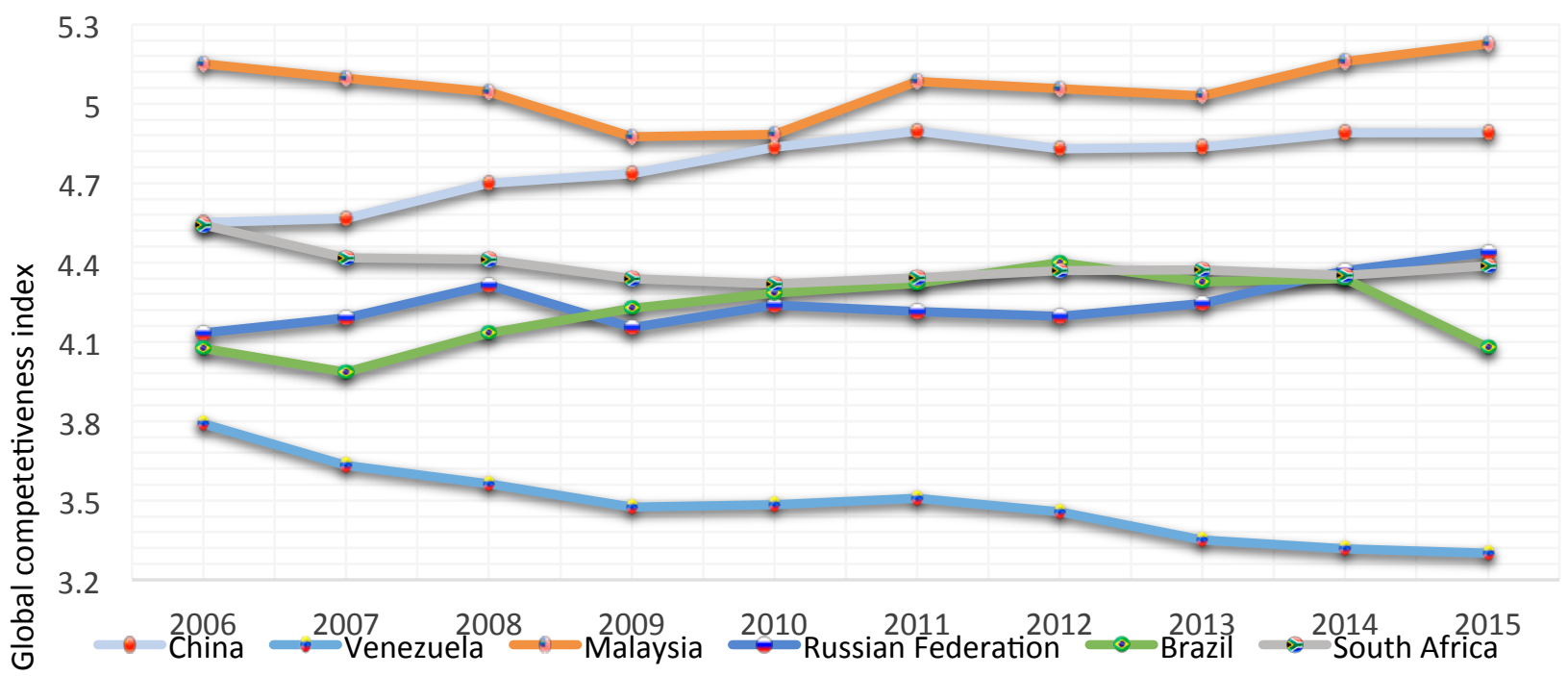

Figure 4 Global competitiveness index of some countries in the world (Global Competitiveness Report 2015-2016)

Let's refer to the analysis of the dynamics of changes in the three major sub-indices that determine the value of the Global competitiveness index of South Africa (see Figure 5). 


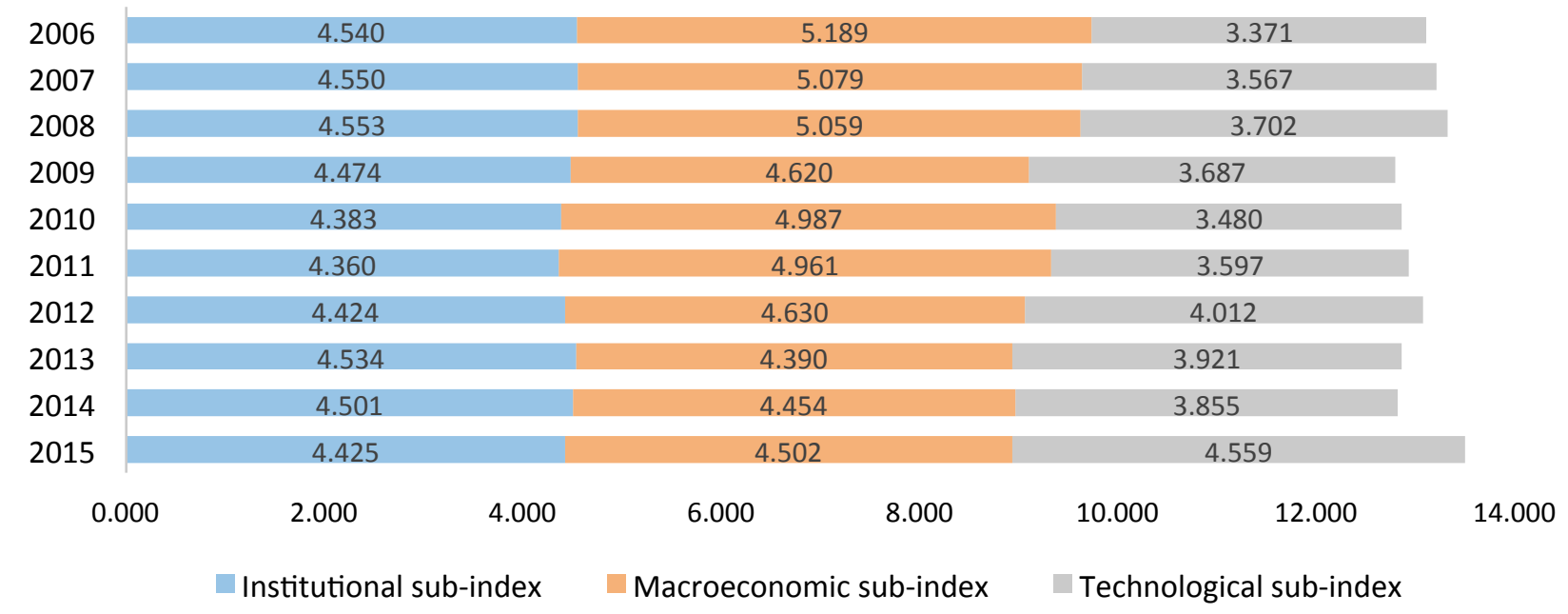

Figure 5. Integral features of Global competitiveness index of South Africa (Global Competitiveness Report 2015-2016)

During the reporting period, the value of institutional sub-index has not changed and the average varies from 4.4 to 4.5 points out of 7 possible. The highest rank received by the country is on such indicators as "compliance to auditing and reporting standards" (6.6 points), "protection of the interests of minority shareholders" (6 points), "intellectual property protection" (5.4 points).

With regard to macroeconomic sub-index, there are obvious negative changes observed: there was a decrease in this indicator with 5.2 (2006) to 4.5 (2014). The main factors which caused this change were:

- increase of inflation rate, from $4.3 \%$ to $6.4 \%$ (in 2010 to 2014 year respectively);

- increase of the state budget deficit, which last 5 years stands at $4.5 \%$ of GDP;

- Increase of public debt.

Technology sub-index in 2015 has grown significantly due to the increase of Internet users and the number of mobile subscribers. Relatively high evaluation of sub-index is associated with significant level of technology absorption at the firm level and the increase in use of new technologies.

\section{STRATEGIC ANALYSIS OF SOUTH AFRICA INVESTMENT POSITION}

For a comprehensive and intuitive analysis of external factors we use the method of the SWOTanalysis, adapting it to study the issue, taking advantage of PESTLE-analysis to facilitate systematization of the impact factors.

In order to determine the country's superiority on separately taken criterion used by the index of competitive advantage (ICP), which is calculated as the quotient of country criterion to the world average. If the ICP> 1 , this means that this criterion in the country is a competitive advantage; if the value varies in the range $0.8-1.0$, the criterion is equivalent to other countries; if the ICP $<0.8$ - in this case the country (South Africa in our case) is less preferred considering this criterion in relation to other countries. More details on this technique is described in (Matraeva 2013).

For indicators which are marked gray, the ICP calculation formula was reversed due to the specificity of reporting criterion (see Table. 1). 
Table : 1 The system of indicators the SWOT-analysis of the investment position of the South Africa in 2010 and 2014

\begin{tabular}{|c|c|c|c|c|c|c|c|}
\hline Name of indicator & $\begin{array}{c}\text { South } \\
\text { Africa, } \\
2010\end{array}$ & $\begin{array}{c}\text { World } \\
\text { average, } \\
2010\end{array}$ & $\begin{array}{c}\text { South } \\
\text { Africa, } \\
2014\end{array}$ & $\begin{array}{c}\text { World } \\
\text { average, } \\
2014\end{array}$ & $\begin{array}{l}\text { ICP, } \\
2010\end{array}$ & $\begin{array}{l}\text { ICP, } \\
2014\end{array}$ & $\begin{array}{c}\text { Change in } \\
\text { ICP } 2010- \\
\text { vs } 2014 \\
(+/-)\end{array}$ \\
\hline \multicolumn{8}{|c|}{ INSTITUTIONAL UNIT } \\
\hline Organized crime & 4,253 & 5,221 & 4,276 & 4,766 & 0,815 & 0,897 & 0,082 \\
\hline $\begin{array}{l}\text { Transparency and clarity of political } \\
\text { decision-making process }\end{array}$ & 4,980 & 4,362 & 4,481 & 4,050 & 1,142 & 1,107 & $-0,035$ \\
\hline The effectiveness of the legal framework & 5,122 & 3,822 & 5,249 & 3,798 & 1,340 & 1,382 & 0,042 \\
\hline Trust to politicians & 2,375 & 3,062 & 2,579 & 3,143 & 0,776 & 0,821 & 0,045 \\
\hline The burden of government regulation & 2,999 & 3,301 & 2,832 & 3,432 & 0,908 & 0,825 & $-0,083$ \\
\hline The strength of investor protection & 8,000 & 5,354 & 8,000 & 5,356 & 1,494 & 1,494 & $-0,001$ \\
\hline Reliability of power structures & 3,431 & 4,294 & 3,637 & 4,233 & 0,799 & 0,859 & 0,060 \\
\hline Protection of borrowers and lenders & 5,613 & 4,313 & 6,093 & 4,163 & 1,302 & 1,464 & 0,162 \\
\hline The quality of railways & 3,347 & 3,158 & 3,423 & 3,342 & 1,060 & 1,024 & $-0,036$ \\
\hline The quality of roads & 4,800 & 3,996 & 4,935 & 4,017 & 1,201 & 1,228 & 0,027 \\
\hline $\begin{array}{l}\text { The quality of air transport } \\
\text { infrastructure }\end{array}$ & 6,055 & 4,662 & 5,985 & 4,363 & 1,299 & 1,372 & 0,073 \\
\hline The quality of electricity supply & 3,785 & 4,564 & 3,578 & 4,499 & 0,829 & 0,795 & $-0,034$ \\
\hline $\begin{array}{l}\text { Quantity of telephone lines (statistical } \\
\text { data) }\end{array}$ & 8,621 & 21,941 & 9,163 & 19,423 & 0,393 & 0,472 & 0,079 \\
\hline \multicolumn{8}{|c|}{ ECONOMICAL UNIT } \\
\hline \multicolumn{8}{|l|}{ Macroeconomic } \\
\hline $\begin{array}{l}\text { Budget deficit or surplus (statistical } \\
\text { data) }\end{array}$ & $-1,200$ & $-2,693$ & $-4,281$ & $-2,423$ & 2,244 & 0,566 & $-1,678$ \\
\hline Inflation rate (statistical data) & 7,111 & 4,521 & 5,752 & 4,558 & 0,636 & 0,792 & 0,157 \\
\hline Savings rate(statistical data) & 15,481 & 21,098 & 13,539 & 20,921 & 0,734 & 0,647 & $-0,087$ \\
\hline $\begin{array}{l}\text { Internal market capacity index } \\
\text { (statistical data) }\end{array}$ & 4,699 & 3,545 & 4,777 & 3,566 & 1,326 & 1,339 & 0,014 \\
\hline $\begin{array}{l}\text { Foreign market capacity index } \\
\text { (statistical data) }\end{array}$ & 5,173 & 4,244 & 5,317 & 4,434 & 1,219 & 1,199 & $-0,020$ \\
\hline \multicolumn{8}{|l|}{ Microeconomic } \\
\hline The size and the effect of the tax burden & 30,200 & 44,659 & 30,100 & 41,129 & 1,479 & 1,366 & $-0,112$ \\
\hline $\begin{array}{l}\text { The number of formal procedures } \\
\text { required to start a new business } \\
\text { (statistical data) }\end{array}$ & 6,000 & 7,873 & 5,000 & 6,797 & 1,312 & 1,359 & 0,047 \\
\hline $\begin{array}{l}\text { The amount of time it takes to start a } \\
\text { new business (statistical data) }\end{array}$ & 22,000 & 26,563 & 19,000 & 23,771 & 1,207 & 1,251 & 0,044 \\
\hline Intensity of local competition & 4,971 & 4,843 & 5,461 & 5,007 & 1,026 & 1,091 & 0,064 \\
\hline $\begin{array}{l}\text { The impact of the rules for foreign direct } \\
\text { investment in the business }\end{array}$ & 4,696 & 4,634 & 3,976 & 4,349 & 1,013 & 0,914 & $-0,099$ \\
\hline $\begin{array}{l}\text { The volume of imports in relation to GDP } \\
\text { (statistical data) }\end{array}$ & 27,967 & 47,000 & 40,679 & 54,165 & 0,595 & 0,751 & 0,156 \\
\hline Diverse purchasing power & 4,086 & 3,451 & 3,979 & 3,436 & 1,184 & 1,158 & $-0,026$ \\
\hline The level of foreign ownership & 5,182 & 4,722 & 5,064 & 4,517 & 1,097 & 1,121 & 0,024 \\
\hline \multicolumn{8}{|l|}{ Effectiveness of labour market } \\
\hline Wages and labour productivity & 3,175 & 3,897 & 2,683 & 3,934 & 0,815 & 0,682 & $-0,133$ \\
\hline The flexibility of wage determination & 3,146 & 4,939 & 2,673 & 4,914 & 0,637 & 0,544 & $-0,093$ \\
\hline \multicolumn{8}{|l|}{ Effectiveness of financial market } \\
\hline The availability of loans & 3,228 & 2,858 & 3,484 & 2,873 & 1,130 & 1,213 & 0,083 \\
\hline
\end{tabular}




\begin{tabular}{|c|c|c|c|c|c|c|c|}
\hline Funding from the local securities market & 4,723 & 3,465 & 5,423 & 3,442 & 1,363 & 1,576 & 0,212 \\
\hline The stability of banking system & 6,462 & 5,069 & 6,503 & 4,845 & 1,275 & 1,342 & 0,068 \\
\hline \multicolumn{8}{|c|}{ TECHNOLOGICAL RENOVATION AND INNOVATION } \\
\hline $\begin{array}{l}\text { Development of technologies at the firm } \\
\text { level }\end{array}$ & 5,409 & 4,861 & 5,435 & 4,674 & 1,113 & 1,163 & 0,050 \\
\hline The potential for innovation & 3,359 & 3,192 & 4,326 & 3,887 & 1,052 & 1,113 & 0,061 \\
\hline Corporate $R \& D$ costs & 3,514 & 3,265 & 3,411 & 3,314 & 1,076 & 1,029 & $-0,047$ \\
\hline The availability of modern technology & 5,482 & 5,064 & 5,498 & 4,858 & 1,083 & 1,132 & 0,049 \\
\hline \multicolumn{8}{|c|}{ BUSINESS ENVIRONMENT PREFECTION } \\
\hline Number of local suppliers & 5,133 & 4,751 & 4,790 & 4,548 & 1,080 & 1,053 & $-0,027$ \\
\hline The quality of local supply & 5,285 & 4,539 & 4,896 & 4,393 & 1,165 & 1,114 & $-0,050$ \\
\hline The volume of marketing & 4,944 & 4,099 & 5,211 & 4,234 & 1,206 & 1,231 & 0,025 \\
\hline The nature of competitive advantage & 3,041 & 3,610 & 3,681 & 3,741 & 0,842 & 0,984 & 0,141 \\
\hline \multicolumn{8}{|c|}{ SOCIAL UNIT } \\
\hline Average life expectancy (statistical data) & 51,477 & 69,920 & 56,098 & 71,109 & 0,736 & 0,789 & 0,053 \\
\hline Infant mortality (statistical data) & 47,900 & 27,925 & 33,300 & 23,489 & 0,583 & 0,705 & 0,122 \\
\hline $\begin{array}{l}\text { Primary school enrollment (statistical } \\
\text { data) }\end{array}$ & 87,467 & 90,787 & 84,996 & 91,434 & 0,963 & 0,930 & $-0,034$ \\
\hline Number of educational institutions & 4,279 & 4,248 & 4,296 & 4,432 & 1,007 & 0,969 & $-0,038$ \\
\hline The quality of the education system & 2,483 & 3,799 & 2,219 & 3,733 & 0,654 & 0,594 & $-0,059$ \\
\hline Personnel trainings & 4,717 & 3,990 & 4,908 & 4,028 & 1,182 & 1,218 & 0,036 \\
\hline
\end{tabular}

Source: Compiled by authors based on statistical data from (Global Competitiveness Report 2015-2016).

Results of the analysis can be represented in the form of three-dimensional graphics (the investment opportunities map, where the vertical delayed overall rating of opportunities and threats across - overall rating of strengths and weaknesses, the point in space corresponds to the size of the volume of FDI).

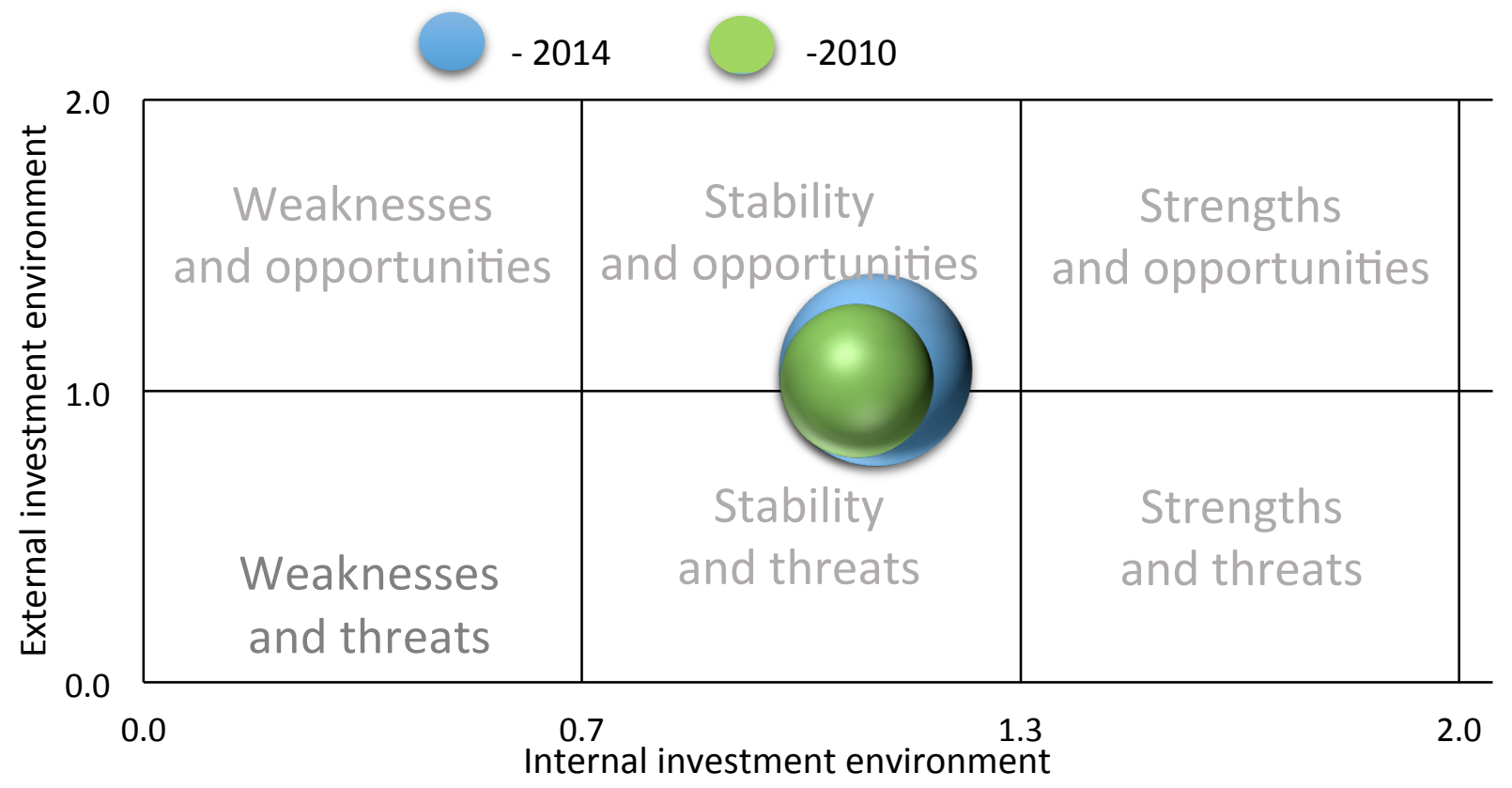

Figure 6: Map of South Africa investment positions in the years 2010 and 2014. Source: Developed by authors. 
Based on current assumptions, trends and identified problems of the strengths and weaknesses of South Africa investment position we can define strategic goals in development of FDI in South Africa in the short-, medium- and long-term. In the case where the ICP takes values in the range of $0.85-0.99$, we can consider it as the short-term goal; if the ICP is in the range 0.7-0.84 - medium-term goal; 0.5-0.69 - long-term goal.

Authors would like to elaborate on some of the goals set in order to clarify existing problems and make recommendations to address them. Given that all the problems are interconnected, their review will be presented in blocks.

\section{Block 1: Organized crime, average life expectancy, infant mortality.}

Many of the problems of modern South Africa are associated with the apartheid - racial conflict between the white minority and the black majority. The inheritance after the collapse of apartheid, South Africa resulted in a high level of social inequality. The Gini index in 2011 was 65.02, which is the second highest in the world. At that time, when 53.8 percent of the population was below the poverty line and lived in abject poverty, and 9,42\% of them survived on less than $\$ 1$ a day, the richest $10 \%$ received $53,78 \%$ of the total income. One of the major problems in the country was the HIV epidemic. In 2012, the cause of death of 240 thousand people was this virus, and the total infection rate of HIV among population aged 15-49 years was $19 \%$, which is a critical indicator. In terms of crime, South Africa held ninth position in the world ranks (31 murder per 100 thousand inhabitants in 2012). The high level of unemployment, the average value of which over the last 5 years was $24.9 \%$ and the mass poverty of the population were the major criminogenic determinants (Boldin 2015).

To solve this problem, it is necessary to improve the level and quality of life of the population first. It is very important to overcome injustice in income distribution, and this should increase the level of remuneration and improve effective state regulation of employment.

\section{Block 2: Wages and labour productivity, the flexibility of wage determination.}

The peculiarities of the African National Congress policy made many skilled people emigrate from the country, and their place is being taken by incompetent personnel. Labor productivity in the country is declining due to this.

It's important to improve the qualification level of employees and actively use the system of motivation of employees. In order to achieve such improvements it's necessary to increase the quality, accessibility and affordability of education.

\section{Block 3: Primary school enrollment, number of educational institutions, the quality of the education system.}

Until the elimination of the apartheid system in South Africa, there had been 19 education departments, for each of the races and ethnic groups living on the territory of the country. Those days the education of white inhabitants was controlled by the Legislative Assembly for whites; education of Indians - the respective Assembly; the education of colored people was under the control of the Department of education and training; education of African ethnic groups was controlled by the Ministry of internal educational systems. Training programs in the universities for whites and non-whites were also different in both primary and secondary schools. Of course, this distinction had a devastating impact on the level of education and training of the African segment of the population (Kananykina 2013). 
At the moment there is a deep need in democratization of the educational system, the introduction of several levels of teaching activity and training as well as expanding the availability of education in the provinces.

\section{Block 4: Trust to politicians, reliability of power structures, the burden of government regulation.}

In South Africa there is much common political disease is corruption. It infected law enforcement agencies and authorities that are associated with economic crimes and crimes in the information sphere. Strict and sometimes conflicting and confusing state requirements in the area of reporting further contribute to the spread of corruption (Sakharov 2012).

According to the latest information police developed a plan to eradicate this disease and it's being implemented currently.

\section{Block 5: The quality of electricity supply, quantity of telephone lines.}

Deficit of the electric power in South Africa began in 2007. Very fast development of many segments of economy was sharply slowed down, mainly for the reason that investments in the new generating capacities, and also in connection with temporary interruptions in power supply weren't carried out. Suddenness of this shock didn't give to the companies the time for adaptation. Moreover, it became at that time obvious that consequences of this shock will be felt still very long. It will be required to raise electricity tariffs for payment of the new generating capacities, and it will be difficult to expand investments to input of these capacities, in particular in power-intensive industries, such as the mining industry.

The South Africa is actively engaged in the solution of this problem: the construction of the new NPPs (IAEA 2013) was planned, the memorandum of a cooperation with Rosatom (Russia) is signed (RBC 2015). Additional recommendations are excessive here.

As for phone lines: it is necessary to implement the modern equipment on automatic telephone exchange, increasing thereby quantity and quality of telephone lines.

\section{Block 6: Budget deficit or surplus, inflation rate, savings rate.}

One of the factors contributing to the growth of the budget deficit is a high level of government spending: $33.7 \%$ of GDP in 2015 (IMF 2016). It is necessary to introduce the authorization of budget expenditures and increase the efficiency of the financial system of the state.

Inflation in the period from 2010 to 2014 has changed from $4.3 \%$ to $6.4 \%$. The reserve Bank of South Africa held anti-inflationary policy of restricting the money supply in the economy, which has yielded results: in 2015, inflation fell to 4.6\%. The downside of such policies - the slowdown in real GDP South Africa from 3\% in 2010 to $1.5 \%$ in 2014.

The government needs to strengthen the mechanisms of the market system, improve the efficiency of socio-economic policy of the state as a whole, and individual provinces and improve policy credibility.

\section{CONCLUSION}

It's noticeable that all the blocks in one degree or another, correlate with each other, so its' necessary to implement all of the above mentioned recommendations comprehensively, to achieve the greatest effect, contributing to increase sustainable flow of foreign direct investment on the territory of South Africa. 
Considering all the analyzed features and development factors of the country, the current position on the investment map, strengths and weaknesses, threats and opportunities, South Africa should make a choice between the strategies for accelerated growth and limited growth in favor of the latter, as it is the least risky path for the country actions. Focus should be placed on the steel sector of the country using preferential taxation. That will allow not only to overcome many existing problems, but also to achieve high ratings of investment attractiveness of the country.

\section{References}

AFRICA by numbers (2015) A focus on South Africa 2014/2015, 12.

BOLDIN, D.S. (2015) A comprehensive assessment of national socio-economic development model of South Africa In Korolkova, N.A. Socio-economic problems and development trends of the global economy. Moscow: APK\&PPRO.

BOLDIN, D.S. (2015) The role of foreign direct investment in the economy of South Africa. In Korolkova, N.A. Socioeconomic problems and development trends of the global economy. Moscow: APK\&PPRO.

GLOBAL COMPETITIVENESS REPORT (2015-2016) [Online] Available: http://reports.weforum.org/globalcompetitiveness-report-2015-2016/economies/\#economy=ZAF [Accessed 2016-11-28]

IMF (2016) Statistical data of International Monetary Fund [Online] Available:

http://www.imf.org/external/pubs/ft/weo/2015/01/weodata/index.aspx. [Accessed 2016-11-28]

INDUSTRIAL POLICY (2001) South Africa Yearbook - 2001/02. — P. 155.

IAEA (2013) International Atomic Energy Agency Director General Yukiya Amano's visit to South Africa highlights the importance of continued discussion on nuclear energy post-Fukushima [Online] Available:

https://www.issafrica.org/iss-today/why-the-iaea-director-generals-visit-to-south-africa-matters [Accessed 2016-11-28]

KANANYKINA, E.S. (2013) The system of modern education South Africa // NB: problems of policy and society, 7, 73-93.

MATRAEVA, L.V. (2013) Methodology of statistical analysis of investment attractiveness of Russian regions for foreign investors. Moscow: Dashkov \& K.

RBC (2015) "Rosatom" have signed the Memorandum of cooperation with South Africa [Online] Available http://www.rbc.ru/rbcfreenews/559e0fb19a794780bec39946. [Accessed 2016-11-28]

SAKHAROV, A.G. (2012) South Africa / Bulletin of international organizations, 4(39), 171-183.

UNCTAD (2016) Statistical data of UN Conference on trade and development [Online] Available: http://unctadstat.unctad.org/EN. [Accessed 2016-11-28] 